\title{
DAMPAK URBANISASI BAGI PEMBANGUNAN MANUSIA 2010-2016 Studi Kasus: Jakarta, Surabaya dan Medan
}

\author{
Iwan Prasodjo \\ Fakultas Ekonomi Universitas Tarumangara \\ Email: iwanp@fe.untar.ac.id
}

\begin{abstract}
This article discusses the effect of urbanization on Human Development Index during 2010-16. It shows that Jakarta has the highest population growth and Gross Domestic Regional Product. However, Surabaya has the highest Human Development Index. Eventhough, Jakarta, with the highest Gross Domestic Regional Product, does not indicate the highest Human Development Index. On the other hand, Medan has the lowest Gross Domestic Regional Product. Not only Medan has the lowest Gross Domestic Regional Product, but also it has the lowest Human Development Index.
\end{abstract}

Keywords: Urbanization, Gross Domestic Regional Product, Human Development Index.

\begin{abstract}
Abstrak :Artikel ini membahas dampak urbanisasi bagi Indeks Pembangunan Manusia dalam periode 2010-2016. Jakarta memiliki tingkat pertumbuhan penduduk tertinggi yang diikuti dengan tingginya Produk Domestik Regional Bruto (PDRB). Meskipun Jakarta memiliki PDRB tertinggi, namun Jakarta tidak memiliki Indeks Pembangunan Manusia (IPM) tertinggi. Surabaya memiliki IPM tertinggi. Di lain pihak, Medan memiliki tingkat PDRB tertendah. Rendahnya PDRB Medan juga diikuti dengan rendahnya IPM.
\end{abstract}

Kata Kunci: Urbanisasi, Produk Domestik Regional Bruto, Indeks Pembangunan Manusia

\section{PENDAHULUAN}

Urbanisasi menjadi suatu gejala sosial yang menarik perhatian dewasa ini. Urbanisasi biasanya diartikan secara kuantitatif sebagai proses berpindahnya penduduk dari daerah pedesaan ke kota.Gerak penduduk dari desa ke kota sering dipandang sebagai suatu masalah yang merisaukan. Hal ini disebabkan oleh cara memandang masalah urbanisasi dari sudut daya dukung ekonomis kota terhadap pendatang baru. Pertambahan fasilitas pendidikan, kesehatan dan lapangan kerja baru tidak sepadan dengan pertambahan penduduk, karena arus urbanisasi di samping pertambahan secara alamiah.

Salah satu faktor pemicu urbanisasi adalah perbedaan ketidakmerataan fasilitas pembangunan antara daerah pedesaan dan perkotaan. Sebagai akibatnya kota menjadi faktor penarik bagi para migran untuk mencari pekerjaan dan penghidupan yang lebih layak. Secara demikian urbanisasi dapat dipandang sebagai suatu proses perubahan yang wajar dalam upaya meningkatkan kesejahteraan penduduk.

Secara kualitatif urbanisasi berarti proses pengkotaan atau semakin berubahnya lingkungan hidup manusia menjadi bercirikan kehidupan kota. Pembangunan tidak akan terjadi tanpa urbanisasi demikian pula sebaliknya. Urbanisasi tidak hanya merupakan akibat, tapi juga sebab dari pembangunan ekonomi. Urbanisasi dapat dianggap sebagai prakondisi untuk modernisasi dan pembangunan. Apabila kota dianggap merupakan 
prakondisi untuk modernisasi dan pembangunan, maka arus urbanisasi dapat dipandang sebagai faktor yang berpengaruh terhadap pembangunan manusia.

Indeks Pembangunan Manusia (IPM) menjelaskan bagaimana penduduk dapat mengakses hasil pembangunan dalam memperoleh pendapatan, kesehatan dan pendidikan.Tulisan ini hendak mengkaji dampak urbanisasi dalam mengakses hasil pembangunan. Dalam kajian ini akan dipilih tiga kota terbesar di Indonesia yang dapat dianggap tingkat pertumbuhan urbanisasi terbesar, yaitu Jakarta, Surabaya dan Medan.

Pengertian Urbanisasi. Urbanisasi menurut Butar Butar (2014), adalahmeningkatnya jumlah penduduk di daerah perkotaan yang disebabkan oleh pertambahan penduduk yang berasal dari penduduk kota sendiri atau yang berasal dari penduduk desa yang bermukim dan berkembang di kota. Di samping itu dalam ilmu lingkungan, urbanisasi dapat diartikan sebagai suatu proses pengkotaan suatu wilayah. Proses pengkotaan ini dapat diartikan dalam dua pengertian. Pertama, urbanisasi merupakan suatu perubahan secara esensial unsur fisik dan sosial ekonomi dan budaya wilayah karena percepatan kemajuan ekonomi. Contohnya daerah Serpong dan Karawaci yang berubah dari desa ke kota karena adanya kegiatan industri. Kedua, urbanisasi merupakan banyaknya penduduk yang pindah dari desa ke kota, karena adanya daya tarik (pull factor) di kota, seperti kesempatan kerja.

Harjoko (2010) mendefinisikan urbanisasi sebagai suatu proses perubahan masyarakat dan kawasan dalam suatu wilayah yang non urban menjadi urban. Secara spasial, ini dikatakan sebagai suatu proses diferensiasi dan spesialisasi pemanfaatan ruang di mana lokasi tertentu menerima bagian pemukim dan fasilitas yang tidak proporsional.

Kayono dalam Abbas (2002) memberikan pengertian urbanisasi sebagai perpindahan dan pemusatan penduduk secara nyata yang memberi dampak dalam hubungannya dengan masyarakat baru yang dilatar belakangi oleh faktor sosial, ekonomi, politik dan budaya. Sementara Keban dalam Abbas (2002) berpendapat bahwa urbanisasi tidak hanya berarti dalam konteks demografi saja karena urbanisasi mengandung pengertian yang multidimensional. Urbanisasi dari pendekatan demografis berarti sebagai suatu proses peningkatan konsentrasi penduduk di perkotaan. Proporsi penduduk yang tinggal menjadi bertambah yang biasanya secara sederhana konsentrasi tersebut diukur dari proporsi penduduk yang tinggal di perkotaan, kecepatan perubahan proporsi tersebut dan perubahan jumlah pusat kota. Sedangkan urbanisasi menurut pendekatan ekonomi politik didefinisikan sebagai transformasi sosial ekonomi yang timbul sebagai akibat dari perkembangan dan ekspansi kapitalisme.

Perkembangan Urbanisasi. Pada tahun 1971 di Indonesia hanya ada 17,5\% penduduk berdiam di kota. Persentase penduduk yang tinggal di daerah perkotaan pada tahun 1980 masih menunjukkan angka kurang dari 25\%, yaitu 22,4\% (Hutajulu, 1985: 585). Selama periode 1971-1980 tingkat urbanisasi di Indonesia masih tergolong rendah.

Tingkat urbanisasi di Indonesia meningkat pesat selama 43 tahun dalam periode 1971-2014. Perkembangan urbanisasi Indonesia meningkat pesat dengan mencapai 53\% tahun 2014 (Nguyen, 2018: 322). Tingkat urbanisasi ini relatif tinggi dibandingkan negara di Asia Tenggara selama periode 1993-2014. Urbanisasi di Asia Tenggara meningkat dari rata-rata 38,69\% tahun 1993 menjadi 50,15\% tahun 2014.Indonesia, Malaysia dan Brunei mencapai tingkat urbanisasi di atas 50\%. Urbanisasi di Muangthai baru mencapai 50\%, sedangkan Filipina, Vietnam dan Kamboja masih belum mencapai 50\% (Nguyen, 2018: 322).Apabila proses pertumbuhan proporsi penduduk yang tinggal di daerah perkotaan 
diartikan sebagai urbanisasi, maka tingkat urbanisasi di Indonesia sudah dapat dikategorikan relatif tinggi. Tiga kota terbesar di Indonesia yang dapat dianggap tingkat pertumbuhan urbanisasi terbesar, yaitu Jakarta, Surabaya dan Medan. Jumlah penduduk di Jakarta, Surabaya dan Medan dalam periode 2010-2016 dapat dilihat pada Tabel 1.

Tabel 1.Jumlah Penduduk di Jakarta, Surabaya dan Medan 20102016

\begin{tabular}{cccc}
\hline Kota & \multicolumn{2}{c}{ Jumlah Penduduk (ribu) } & $\begin{array}{c}\text { Laju Pertumbuhan Penduduk } \\
(\%)\end{array}$ \\
\hline & 2010 & 2016 & $2010-2016$ \\
Jakarta & 9.640 .406 & 10.277 .628 & 6,61 \\
Surabaya & 2.771 .615 & 2.862 .406 & 3,28 \\
Medan & 2.097 .610 & 2.229 .408 & 6,28 \\
\hline
\end{tabular}

Sumber : www.bps.go.id

Jakarta mengalami pertumbuhan penduduk terbesar $(6,61 \%)$ selama periode 20102016. Penduduk Jakarta meningkat dari 9,64 juta tahun 2010 menjadi 10,27 juta tahun 2016atau bertambah 637.222 orang. Jumlah penduduk ini belum dihitung mereka yang tinggal di Bogor, Depok, Tanggerang dan Bekasi. Sebagian besar penduduk yang tinggal di sekitar kota Jakarta mencari penghasilan di Jakarta pada siang hari. Urbanisasi di Jakarta bertumbuh pesat, karena Jakarta sebagai ibukota negara juga merupakan pusat administrasi pemerintahan, pusat kegiatan sosial dan ekonomi. Jakarta bisa jadi mempuyai daya tarik yang kuat untuk menarik migran berpindah.

MeskipunSurabaya merupakan ibukota provinsi Jawa Timur, namun Surabaya mengalami pertumbuhan terendah yakni 3,28\% selama kurun waktu 2010-2016. Jumlah penduduk Surabaya hanya bertambah 90.791 orang dari 2,77 juta (2010) menjadi 2,86 juta (2016). Sedangkan Medan sebagai ibukota provinsi Sumatera Utara, mengalami pertumbuhan penduduk terbesar kedua (6,28\%) selama periode 2010-2016. Jumlah penduduk Medan bertambah 131.798 orang dari 2,09 juta (2010) menjadi 2,23 juta (2016).

Urbanisasi tidak hanya merupakan akibat, tapi juga sebab dari pembangunan ekonomi. Pertambahan penduduk juga berarti bertambahnya angkatan kerja di perkotaan. Bertambahnya tenaga kerja pada gilirannya dapat meningkatkan output produksi barang dan jasa di perkotaan. Produk Domestik Regional Bruto di Jakarta, Surabaya dan Medan dapat dilihat pada kurva berikut.

Pada gambar 1 dapat dilihat kurva PDRB Jakarta di atas PDRB Surabaya dan Medan. Selain Jakarta mengalami urbanisasi terbesar, Jakarta juga memiliki PDRB tertinggi. Demikian pula PDRB Jakarta cenderung meningkat di atas PDRB Surabaya dan Medan selama periode 2011 - 2015.Perkembangan PDRB Jakarta, Surabaya dan Medan selama kurun waktu 20112015 dapat dilihat pada Tabel 2. 


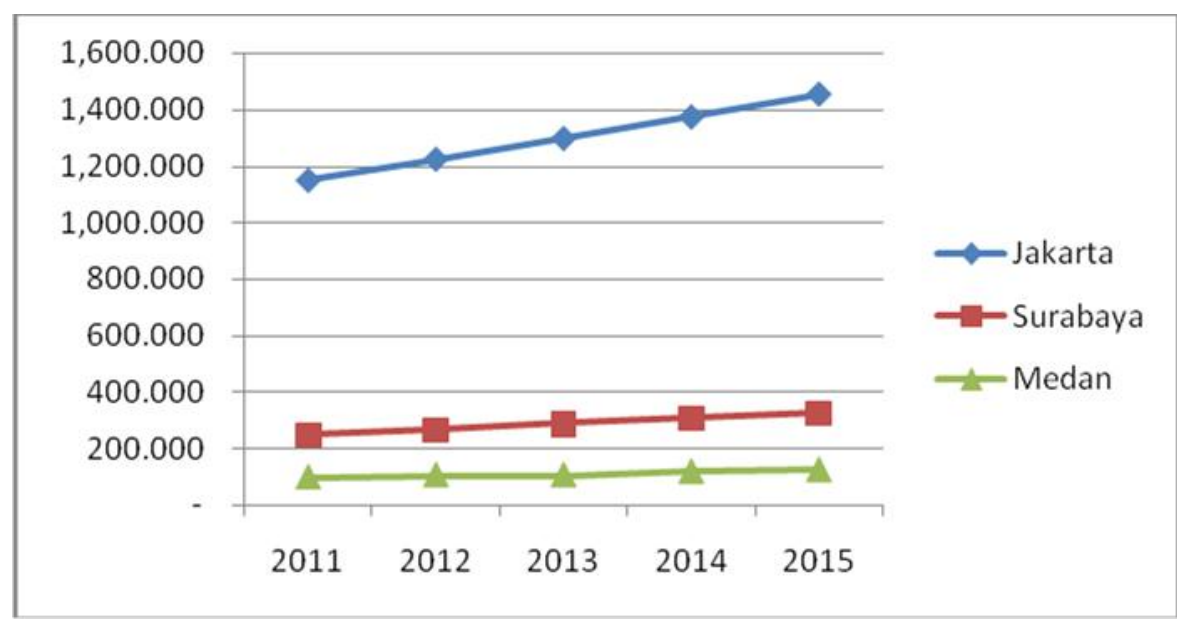

Gambar 1. PDRB atas harga konstan (tahun dasar 2010) di Jakarta, Surabaya dan Medan 2011-2015 (triliun Rupiah)

Sumber :www.bps.go.id

Tabel 2. PDRB atas harga konstan (tahun dasar 2010) di Jakarta, Surabaya dan Medan 2010-2016 (triliun Rupiah)

\begin{tabular}{|c|c|c|c|c|c|c|}
\hline & 2011 & 2012 & 2013 & 2014 & 2015 & $\begin{array}{c}\text { Pertum- } \\
\text { buhan } \\
(\%)\end{array}$ \\
\hline Jakarta & $1.147,558$ & $1.222,527$ & $1.296,694$ & $1.373,386$ & $1.454,345$ & 26,73 \\
\hline Surabaya & 247,686 & 247,686 & 286,050 & 305,957 & 324,227 & 30,90 \\
\hline Medan & 97,675 & 105,162 & 105,162 & 117,528 & 124,277 & 27,23 \\
\hline
\end{tabular}

Sumber : www.bps.go.id

Tabel 2 menunjukkan meskipun Jakarta memiliki PDRB tertinggi, namun pertumbuhan PDRB Surabaya tertinggi sebesar 30,9\% selama 2011 - 2015. PDRB Surabaya meningkat dari 247,68 triliun Rupiah tahun 2011 menjadi 324,23 triliun Rupiah tahun 2015. PDRB kota Surabaya terus mengalami kenaikan. Tahun 2011 besaran PDRB kota Surabaya mencapai 247,69triliun Rupiah, bertahandi 247,69 triliun Rupiah di tahun 2012. Besaran PDRB kota Surabaya kembali meningkat menjadi 286,05 triliun Rupiah di tahun 2013 dan mencapai 305,96 triliun Rupiah di tahun 2014. Tahun 2015 nilai PDRB tersebut menembus angka 324,27 triliun Rupiah. Jika dirata-ratakan dalam 5 tahun terakhir (2011-2015) nilai PDRB kota Surabaya meningkat 6,96\% tiap tahun.

Pertumbuhan PDRB Medan termasuk terbesar kedua setelah Surabaya yakni sebesar 27,23\% selama 2011 - 2015. PDRB Medan meningkat dari 97,67 triliun Rupiah tahun 2011 menjadi 124,27 triliun Rupiah tahun 2015.PDRB Medan meningkat dari 247,68 triliun Rupiah tahun 2011 menjadi 324,23 triliun Rupiah tahun 2015. PDRB kota Medan terus mengalami kenaikan. Tahun 2011 besaran PDRB kota Medan mencapai 247,69triliun Rupiah, meningkat menjadi 105,16 triliun Rupiah di tahun 2012. Besaran PDRB kota Medanbertahan di 105,16triliun Rupiah di tahun 2013 dan meningkat lagimencapai 117,53 triliun Rupiah di tahun 2014. Tahun 2015 nilai 
PDRB tersebut menembus angka 124,28triliun Rupiah. Jika dirata-ratakan dalam 5 tahun terakhir (2011-2015) nilai PDRB kota Medan meningkat 6,21\% tiap tahun.

Sedangkan pertumbuhan PDRB Jakarta menempati urutan ketiga, setelah Surabaya dan Medan. PDRB Jakarta meningkat dari 1.147,5 triliun Rupiah tahun 2011 menjadi 1.454,3 triliun Rupiah tahun 2015.Jakarta memiliki Dana Bagi Hasil (DBH) yang besar, karena merupakan pusat pemerintahan dan beroleh dari Dana Bagi Hasil pajak.PDRB kota Jakarta terus mengalami kenaikan. Tahun 2011 besaran PDRB kota Jakarta mencapai 1.147,56 triliun Rupiah, meningkat menjadi 1.222,53triliun Rupiah di tahun 2012. Besaran PDRB kota Jakartaterus meningkatmenjadi 1.296,69triliun Rupiah di tahun 2013 dan meningkat lagi mencapai 1.373,39triliun Rupiah di tahun 2014. Tahun 2015 nilai PDRB tersebut mencapai angka 1.454,35triliun Rupiah. Jika dirata-ratakan dalam 5 tahun terakhir (2011-2015) nilai PDRB kota Jakarta meningkat $6,1 \%$ tiap tahun.

Besarnya PDRB dan urbanisasi memberi kesempatan penduduk untuk dapat memperoleh hasil pembangunan. Indeks Pembangunan Manusia (IPM) menjelaskan bagaimana penduduk dapat mengakses hasil pembangunan dalam memperoleh pendapatan, kesehatan, pendidikan, dan hasil pembangunan lainnya. IPM diperkenalkan oleh United Nations Development Programme(UNDP) pada tahun 1990 dan dipublikasikan secara berkala dalam laporan tahunan Human Development Report (HDR). IPM mengukur 3 (tiga) dimensi dasar pembangunan manusia, yaitu :umur panjang dan hidup sehat, pengetahuan, dan standar hidup layak. IPM merupakan indikator penting untuk mengukur keberhasilan dalam upaya membangun kualitas hidup manusia.

Indeks Pembangunan Pembangunan Manusia Indonesia adalah 0,69 tahun 2015. Ini menempatkan Indonesia pada kategori menengah pembangunan manusia yaitu 113 dari 188 negara. Nilai IPM Indonesia adalah 30,5 persen meningkat daripada nilai tahun 1990. Ini menunjukkan kemajuan Indonesia dalam angka harapan hidup saat kelahiran, rata-rata lama bersekolah selama periode itu. (www.id.undp.org/content/indonesia). Perhatian yang terlalu besar pada IPM ratarata nasional dapat menutupi kelemahan keragamanan kehidupan manusia. Untuk mengatasi masalah ini akan dilihat IPM di tiga kota terbesar di Indonesia.

Kota besar mempunyai daya tarik bagi para migran dari desa atau kota kecil untuk memperoleh hidup yang layak. Indeks Pembangunan Manusia (IPM) di 3 kota terbesar di Indonesia dapat merupakan indikator perbaikan kehidupan penduduknya. Perbandingan IPM di Jakarta, Surabaya dan Medan selama periode 2013-2015 dapat dilihat pada gambar No. 2

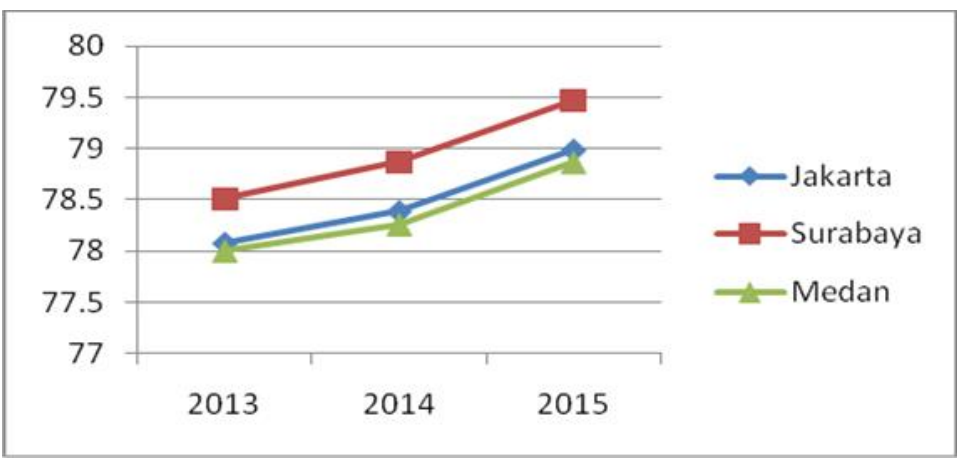

Gambar 2.IPM di Jakarta, Surabaya dan Medan 2013 - 2015 Sumber : www.bps.go.id 
Gambar No 2 menunjukkan bahwa IPM di Jakarta, Surabaya dan Medan cenderung meningkat sejak 2013-2015. Ternyata IPM Surabaya tertinggi daripada IPM Jakarta dan IPM Medan. Ini menunjukkan bahwa PDRB Jakarta yang tertinggi tidak menunjukkan IPM juga tertinggi. Adapun IPM Medan terendah. Ini berrti pembangunan ekonomi di Medan belum mampu meningkatkan kualitas manusia di bidang kesehatan dan pendidikan,Perkembangan IPM di Jakarta, Surabaya dan Medan dapat dilihat di Tabel berikut.

Tabel 3. IPM di 3 kota besar di Indonesia 2010-2016

\begin{tabular}{cccccccc}
\hline Kota & 2010 & 2011 & 2012 & 2013 & 2014 & 2015 & 2016 \\
\hline Jakarta & 76,31 & 76,98 & 77,53 & 78,08 & 78,39 & 78,99 & 79,60 \\
Surabaya & 77,2 & 77,62 & 78,05 & 78,51 & 78,87 & 79,47 & 80,38 \\
Medan & 77,02 & 77,54 & 77,78 & 78 & 78,26 & 78,87 & 79,34 \\
Nasional & 66,53 & 67,09 & 67,7 & 68,31 & 68,9 & 69,55 & 70,18 \\
\hline
\end{tabular}

Sumber : https://www.bps.go.id/dynamictable/2017/09/05/1269/indeks-pembangunanmanusia-menurut-kabupaten-kota-2016-metode-baru-.htm

Secara umum IPM di Jakarta, Surabaya dan Medan di atas rata-rata nasional selama kurun waktu 2010-2016. IPM di ketiga kota ini cenderung meningkat dari 2010 hingga 2016. IPM di Surabaya menunjukkan tertinggi dibandingkan Jakarta dan Medan. Namun jika dilihat menurut propinsi, IPM DKI Jakarta dengan 79,60 (2016) menunjukkan tinggi (BPS, 2016)Jakarta Selatan memiliki status IPM sangat tinggi $(83,94)$ tahun 2016. Surabaya juga memiliki IPM sangat tinggi $(80,38)$ tahun 2016. Ini menunjukkan bahwa mereka yang tinggal di kota besar seperti Jakarta dan Surabaya mempunyai kesempatan lebih besar untuk meningkatkan taraf hidupnya.

Indeks Pembangunan Manusia (IPM) mengukur capaian pembangunan manusia berbasis sejumlah komponen dasar kualitas hidup. IPM merupakan cerminan dari kualitas kesehatan (angka harapan hidup saat lahir), pendidikan (lama bersekolah) dan perekonomian (pengeluaran per kapita). Indeks Pembangunan Manusia Surabaya 20102015 dapat dilihat pada Tabel 4.

Tabel 4. Indeks Pembangunan Manusia Kota Surabaya 2010-2015

\begin{tabular}{cccccc}
\hline Tahun & AHH & EYS & MYS & $\begin{array}{c}\text { Pengeluaran } \\
\text { (ribuan Rupiah) }\end{array}$ & IPM \\
\hline 2010 & 73,76 & 12,88 & 9,76 & 14.473 & 77,2 \\
2011 & 73,78 & 12,96 & 9,85 & 14.777 & 77,62 \\
2012 & 73,8 & 13,05 & 9,95 & 15.104 & 78,05 \\
2013 & 73,83 & 13,13 & 10,05 & 15.488 & 78,51 \\
2014 & 73,85 & 13,44 & 10,07 & 15.492 & 78,87 \\
2015 & 73,85 & 13,52 & 10,24 & 15.991 & 79,47 \\
\hline
\end{tabular}

Sumber : BPS, Surabaya

dalamAngka

AHH = Angka Harapan Hidup (Life Expectation)

EYS = Harapan Lama Sekolah (Expected Years of Schooling)

MYS = Rata-rata Lama Sekolah (Mean Years of Schooling) 
Angka harapan hidup rata-rata penduduk Surabaya adalah 73,81 tahun selama periode 2010- 2015 berarti di atas rata-rata nasional 70,78 tahun 2015. Adapun harapan lama sekolah rata-rata adalah 13,16 tahun selama 2010-2015. Ini berarti harapan mereka ingin bersekolah hingga tamat SMA. Namun kenyataan menunjukkan rata-rata lama sekolah adalah 9,99 tahun atau tamat SMP. Sedangkan angka IPM penduduk Surabaya cenderung meningkat setiap tahun dari 77,2 tahun 2010 hingga 79,47 tahun 2015. Angka IPM penduduk Surabaya ini tergolong tinggi. Peningkatan IPM kota Surabaya disebabkan oleh peningkatan pada indeks pendidikan.

Adapun Indeks Pembangunan Manusia Jakarta, Surabaya dan Medan 2016 dapat dilihat pada Tabel 5 .

Tabel 5. Indeks Pembangunan Manusia Jakarta, Surabaya dan Medan 2016

\begin{tabular}{|c|c|c|c|c|c|}
\hline \multirow{2}{*}{ Kota } & $\mathrm{AHH}$ & HLS & RLS & \multirow{2}{*}{$\begin{array}{l}\text { Pengeluaran } \\
\text { (ribuan Rupiah) }\end{array}$} & \multirow{2}{*}{ IPM } \\
\hline & (tahun) & (tahun) & (tahun) & & \\
\hline Jakarta & 72,49 & 12,73 & 10,88 & 17,468 & 79,60 \\
\hline Surabaya & 73,87 & 13,99 & 10,44 & 16,295 & 80,38 \\
\hline Medan & 72,34 & 14,06 & 11,18 & 14,393 & 79,34 \\
\hline
\end{tabular}

Sumber : BPS, Indeks Pembangunan Manusia 2016

AHH = Angka Harapan Hidup (Life Expectation)

HLS = Harapan Lama Sekolah (Expected Years of Schooling)

RLS = Rata-rata Lama Sekolah (Mean Years of Schooling)

Kualitas kesehatan yang diukur dari Angka Harapan Hidup penduduk Surabaya tertinggi (73,87 tahun) diikuti Jakarta (72,49 tahun) dan terendah adalah Medan (72,34 tahun) tahun 2016. Dari segi kualitas pendidikan yang diukur dari Harapan Lama Sekolah,penduduk Medan tertinggi adalah 14,06 tahun 2016. Harapan mereka ingin bersekolah hingga perguruan tinggi. Ini bisa jadi penduduk Medan lebih menghargai pendidikan hingga perguruan tinggi sebagai sarana memperoleh pekerjaan baik sebagai pegawai negeri atau swasta Namun kenyataan data menunjukkan rata-rata lama sekolah adalah 11,18 tahun atau SMA kelas 2.Demikian pula penduduk Surabaya memiliki Harapan Lama Sekolah 13,99 tahun tahun 2016. Penduduk Surabaya ingin bersekolah hingga perguruan tinggi, namun dalam kenyataannya data menunjukkan rata-rata lama sekolah adalah 10,44 tahun atau setaraf SMA kelas 1. Sedangkan Angka Harapan Sekolah di Jakarta 12,73 tahun yang berarti tamat SMA. Namun dalam kenyataannya rata-rata lama sekolah penduduk Jakarta adalah 10,88 tahun atau SMA kelas 1. Ini mungkin setelah itu mereka masuk pasar tenaga kerja.

Dilihat dari kualitas ekonomi yang diukur dari pengeluaran, penduduk Jakarta mengeluarkan uang terbesar $(17,468,000)$ selama tahun 2016. Ini sejalan dengan besarnya PDRB Jakarta yang tertinggi. Penduduk Surabaya melakukan pengeluaran (16.295.000 Rupiah) terbesar kedua setelah Jakarta selama 2016.

Adapun penduduk Medan melakukan pengeluaran terendah (14.293.000 Rupiah) selama tahun 2016. Ini sejalan dengan PDRB Medan yang terendah (lihat Gambar 1). Kemajuan pembangunan manusia secara umum dapat ditunjukkan dengan melihat perkembangan indeks pembangunan manusia (IPM) yang mencerminkan capaian kemajuan di bidang pendidikan, kesehatan dan ekonomi. Dengan melihat perkembangan 
angka IPM tiap tahun tampaknya kemajuan yang dicapai Medan dalam pembangunan manusia tidak terlalu signifikan. Angka IPM Medan meningkat dari 78,00 pada tahun 2013 menjadi 78,87 pada tahun 2015 (lihat Tabel 3).

Kesenjangan. Di lain pihak menurut Kanbur dan Zhuang (2013:145), urbanisasi di Indonesia menyumbang lebih dari 50\% kesenjangan tingkat nasional. Menurut Kuncoro (2017: 12), semakin tinggi penduduk perkotaan, maka akan meningkatkan ketimpangan. Gini koefisien merupakan ukuran kesenjangan distribusi pendapatan. Sejak 2011 Gini koefisien mengalami kenaikan dari 0,38 pada tahun 2010 menjadi 0,41 . Ini berarti kesenjangan distribusi pendapatan meningkat. Selama periode 2011-2015 koefisien Gini tidak mengalami perubahan pada 0,41 yang berarti tingkat kesenjangan distribusi pendapatan relatip sedang. Indeks Pembangunan Manusia meningkat, namun kesenjangan distribusi pendapatan tetap $(0,41)$. Kenaikan kesenjangan distribusi pendapatan sejak 2010 bisa jadi disebabkan pesatnya pembangunan ekonomi yang lebih dinikmati $20 \%$ penduduk terkaya dan $40 \%$ penduduk menengah daripada $40 \%$ penduduk termiskin (Kuncoro, 2017). Peningkatan kesenjangan distribusi pendapatan berkorelasi negatip dengan kemikinan (Kuncoro, 2017)

Kesenjangan distribusi pendapatan di antara warga penduduk kota besar dapat dilihat di gambar berikut.

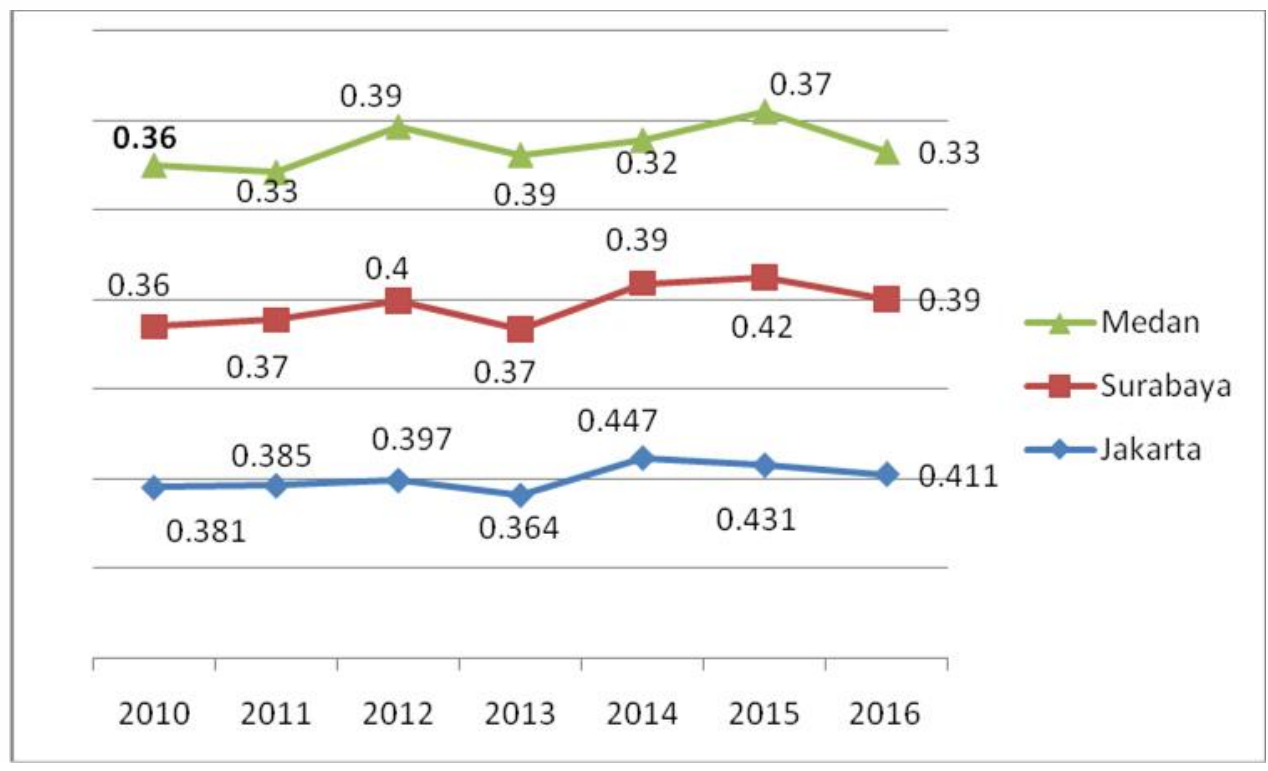

Gambar 3. Kesenjangan Distribusi Pendapatan di Jakarta, Surabaya dan Medan 2010-2016

Sumber: Badan Pusat Statistik

Kesenjangan di Jakarta, Surabaya dan Medan termasuk sedang. Meskipun demikian Kesenjangan di Jakarta cenderung meningkat dari 0,381 (2010) menjadi 0,411 (2016). Demikian pula kesenjangan di Surabaya meningkat dari 0,36 (2010) menjadi 0,39 (2016). Ini menunjukkan kenaikan pembangunan ekonomi yang ditunjukkan dengan kenaikan PDRB juga diikuti dengan kenaikan kesenjangan ekonomi. Hanya Medan yang mengalami penurunan kesenjangan dari 0,36 (2010) menjadi 0,33 (2016). Rendahnya 
kesenjangan ekonomi di Medan juga diikuti dengan rendahnya PDRB Medan (lihat Tabel 2).

Tabel 6. Gini Koefisien di Jakarta, Surabaya dan Medan 2010-2016

\begin{tabular}{cccc}
\hline Tahun & Jakarta & Surabaya & Medan \\
\hline 2010 & 0,38 & 0,36 & 0,36 \\
2011 & 0,39 & 0,37 & 0,33 \\
2012 & 0,40 & 0,40 & 0,39 \\
2013 & 0,36 & 0,37 & 0,39 \\
2014 & 0,45 & 0,39 & 0,32 \\
2015 & 0,43 & 0,42 & 0,37 \\
2016 & 0,41 & 0,39 & 0,33 \\
Rata-rata : & 0,4 & 0,4 & 0,4 \\
\hline
\end{tabular}

Sumber : Badan Pusat Statistik

Tabel 6 menunjukkan bahwa rata-rata Koefisien Gini di Jakarta, Surabaya dan Medan sama $(0,4)$ selama periode 2010-2016. Kesenjangan di Jakarta, Surabaya dan Medan relatif sama dan menunjukkan peningkatan.

Tingkat Pengangguran Terbuka. Kota dapat menjadi faktor penarik (pull factor) bagi para migran untuk mencari pekerjaan dan penghidupan yang lebih layak. Banyak dari mereka yang berasal dari desa tidak memiliki pendidikan formal dan ketrampilan yang diperlukan sektor formal. Industri padat modal menuntut persyaratan pendidikan formal dan keterampilan yang tidak dapat dipenuhi orang desa (Prasodjo, 2000: 73). Tingkat migrasi desa-kota bisa jadi telah melebihi tingkat penciptaan lapangan kerja perkotaan, sehingga jauh melampaui kemampuan industri untuk menyerap tenaga kerja. Pengangguran terbuka adalah akibat tidak terserapnya angkatan kerja di pasar tenaga kerja. Akibatmya mereka harus bekerja di sektor informal atau menjadi setengah pengangguran di perkotaan. Tingkat pengangguran terbuka di Jakarta, Surabaya dan Medan dapat dilihat pada Tabel 7.

Tabel 7. Pengangguran Terbuka di Jakarta, Surabaya dan Medan (\%)

\begin{tabular}{cccc}
\hline & Jakarta & Surabaya & Medan \\
\hline 2010 & 9,35 & 6,84 & 13,11 \\
2011 & 10,8 & 7,81 & 9,97 \\
2012 & 9,87 & 5,27 & 9,03 \\
2013 & 9,02 & 5,32 & 10,01 \\
2014 & 8,47 & 5,82 & 9,48 \\
2015 & 7,23 & 7,01 & 11,00 \\
2016 & 6,12 & n.a & n.a \\
Rata-rata & 8,69 & 6,35 & 10,43 \\
\hline
\end{tabular}

Sumber : Badan Pusat Statistik

n.a $=$ data tidak tersedia

(not available) 
Data pada Tabel 7 menunjukkan rata-rata tingkat pengangguran tertinggi di Medan $(10,43 \%)$ selama periode 2010 hingga 2015. Jakarta memiliki rata-rata tingkat pengangguran tertinggi $(8,69 \%)$ kedua setelah Medan selama periode 2010-2016. Sedangkan Surabaya memiliki rata-rata tingkat pengangguran terendah $(6,35 \%)$ selama periode 2010 hingga 2015. Namun tingkat pengangguran di Surabaya naik dari $6,84 \%$ tahun 2010 menjadi 7,01\% tahun 2015. Meskipun demikian tingkat pengangguran di Jakarta, Surabaya dan Medan cenderung turun sejak 2010. Tingkat pengangguran di Jakarta turun dari 9,35\% tahun 2010 turun menjadi 6,12 tahun 2016. Tingkat pengangguran di Medan turun dari 13,11\% tahun 2010 turun menjadi 11,00 tahun 2015.

Urbanisasi dan Kemiskinan. Penduduk desa berpindah ke kota untuk mencari pekerjaan. Banyak dari mereka yang berasal dari desa tidak memiliki pendidikan formal dan ketrampilan yang diperlukan sektor formal. Di kota industri padat modal tidak menguntungkan bagi orang miskin. Industri padat modal menuntut persyaratan pendidikan formal dan keterampilan yang tidak dapat dipenuhi orang desa (Prasodjo, 2000: 73). Tingkat migrasi desa-kota bisa jadi telah melebihi tingkat penciptaan lapangan kerja perkotaan, sehingga jauh melampaui kemampuan industri untuk menyerap tenaga kerja. Sektor industri yang padat modal dan lambatnya pertumbuhan investasi dapat menyebabkan tidak terserapnya para migran dari desa. Mereka harus bekerja di sektor informal atau menjadi setengah pengangguran di perkotaan. Ini mengakibatkan rendahnya tingkat pendapatan mereka, sehingga menimbukan kemiskinan.

Kemiskinan ternyata cukup beragam di Jakarta, Surabaya dan Medan pada tahun 2016. Jumlah penduduk miskin tahun 2016 dapat dilihat pada Tabel 8.

Tabel 8. Jumlah dan Persentase Penduduk Miskin di Jakarta, Surabaya dan Medan 2016

\begin{tabular}{ccc}
\hline & Jumlah Penduduk Miskin & \% Penduduk Miskin \\
\hline Kota & $(000)$ & 3,75 \\
Jakarta & 384,3 & 5,63 \\
Surabaya & 161,01 & 9,3 \\
Medan & 206,87 &
\end{tabular}

Sumber: BPS, Jakarta Dalam Angka 2016, Data \& Informasi Kemiskinan Kabupaten/Kota 2016

Tabel 8 menunjukkan bahwa pada tahun 2016 secara absolut penduduk miskin di Surabaya terendah (161.010), namun dari segi persentase Surabaya $(5,63 \%)$ masih lebih baik dari Medan. Di lain pihak, Medan memiliki persentase penduduk miskin terbesar (9,3\%). Pembangunan manusia di bidang kesehatan dan pendidikan (IPM) di Medan juga tertinggal (lihat Gambar 2).Jakarta memiliki penduduk miskin terbesar (384.300), tetapi dari segi persentase terendah (3,75\%) dibandingkan Surabaya dan Medan.

Demikian pula dari segi persentase sejak 2010-2016, Medan memiliki persentase tertinggi diikuti Surabaya dan Jakarta. Perkembangan persentase penduduk miskin Jakarta, Surabaya dan Medan sejak 2010-2016 dapat dilihat pada Gambar 4. 


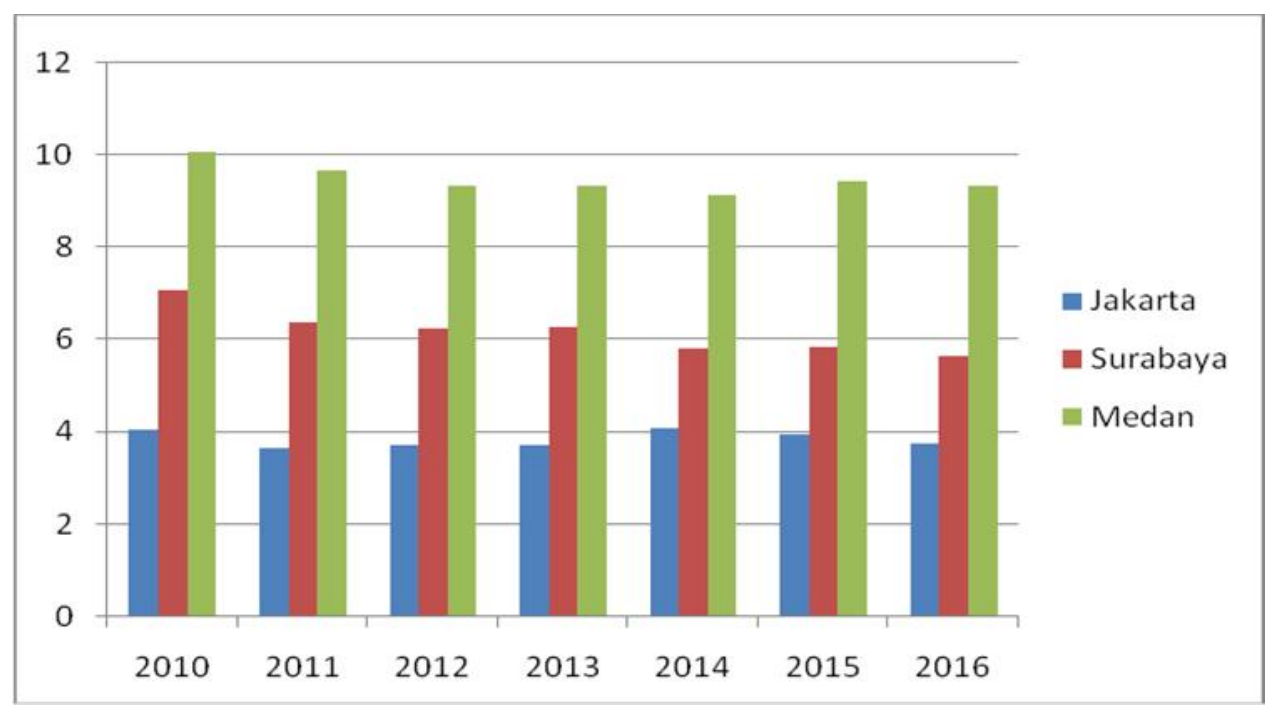

Gambar 4: Tingkat Kemiskinan di Jakarta, Surabaya dan Medan 2010-2016 (dalam \%)

Sumber: BPS, Data \& Informasi Kemiskinan Kabupaten/Kota 2010-2016

Gambar 4 menunjukkan perkembangan persentase penduduk miskin yang relatip stagnan di Jakarta, Surabaya dan Medan. Perkembangan persentase penduduk miskin di Jakarta, Surabaya dan Medan 2010-2016 dapat dilihat pada Tabel 9.

Tabel 9. Kemiskinan di Jakarta, Surabaya dan Medan 2010-2016 (dalam \%)

\begin{tabular}{clll}
\hline \multicolumn{1}{c}{ Tahun } & Jakarta & Surabaya & Medan \\
\hline 2010 & 4,04 & 7,07 & 10,06 \\
2011 & 3,64 & 6,38 & 9,63 \\
2012 & 3,7 & 6,23 & 9,33 \\
2013 & 3,72 & 6,25 & 9,33 \\
2014 & 4,09 & 5,79 & 9,12 \\
2015 & 3,93 & 5,82 & 9,41 \\
2016 & 3,75 & 5,63 & 9,3 \\
Rata-rata : & 3,84 & 6,17 & 9,45 \\
\hline
\end{tabular}

Sumber : BPS, Jakarta Dalam Angka 2016, 2017, Data \& InformasiKemiskinan Kabupaten/Kota 2010-2016

Tingkat kemiskinan tertinggi di Medan (10,06\%), diikuti Surabaya (7.07\%) dan Jakarta (4,04\%). Pernurunan tertinggi terjadi di Surabaya dari 7,07\% (2010) menjadi $5,63 \%$ (2016) atau turun sebesar 0,20\% tiap tahun. Penurunan terendah terjadi di Jakarta dari 4,04\% (2010) menjadi 3,75\% (2016) atau turun sebesar 0,07\% tiap tahun. Jika dilihat dari rata-rata persentase tingkat kemiskinan ternyata Medan tertinggi $(9,45 \%)$, diikuti Surabaya $(6,17 \%)$ dan Jakarta $(3,84 \%)$ selama periode $2010-2016$. Jadi Jakarta memiliki persentase penduduk miskin terendah dibandingkan Medan dan Surabaya. 
Diskusi. Hasil penelitian Winarti (2014) menunjukkan bahwa PDRB berpengaruh positip dan signifikan terhadap Indeks Pembangunan Manusia. Kenaikan PDRB akan meningkatkan Indeks Pembangunan Manusia. Namun ini tidak terbukti di Jakarta. Data menunjukkan bahwa PDRB Jakarta yang tertinggi tidak juga menunjukkan IPM tertinggi. IPM Jakarta di bawah IPM Surabaya (lihat Gambar 2). Di lain pihak, hasil penelitian Winarti (2014) menemukan bahwa kemiskinan berpengaruh negatip dan signifikan terhadap Indeks Pembangunan Manusia di Indonesia. Dengan kata lain, menurunnya tingkat kemiskinan akan meningkatkan Indeks Pembangunan Manusia. Penemuan ini juga berbeda dengan kenyataan di Jakarta. Rendahnya persentase penduduk miskin di Jakarta tidak juga menunjukkan tingginya IPM (lihat Gambar 3 dan Tabel 3).

Meskipun rata-rata persentase penduduk miskin di Jakarta terendah dibandingkan di Surabaya dan Medan, namun kesenjangan distribusi pendapatan meningkat. Kesenjangan distribusi pendapatan makin melebar di Jakarta, sebagaimana ditunjukkan dengan meningkatnya angka Gini ratio di Jakarta dari 0,36 (2013) menjadi 0,45 (2014), 0,43 (2015) dan 0,41 (2016) (lihat Tabel 6). Ini menunjukkan PDRB Jakarta lebih dinikmati $20 \%$ penduduk terkaya daripada $20 \%$ penduduk termiskin. Ini sesuai dengan penemuan Kuncoro, semakin tinggi PDRB per kapita, maka cenderung akan meningkatkan kesenjangan (Kuncoro, 2017). Demikian pula Kuncoro menemukan semakin tinggi penduduk perkotaan (urbanisasi), maka akan meningkatkan kesenjangan (Kuncoro, 2017). Penduduk Jakarta yang tumbuh terbesar dibandingkan Surabaya dan Medan, menunjukkan kesenjangan yang semakin meningkat.

Laju pertumbuhan penduduk atau urbanisasi Surabaya (2010-2016) terendah dibandingkan Jakarta dan Surabaya. Meskipun urbanisasi di Surabaya terendah, namun laju pertumbuhan PDRB tertinggi selama 2011-2015. Di lain pihak, Surabaya memiliki IPM tertinggi dibandingkan Jakarta dan Medan. Kesenjangan yang ditunjukkan dengan koefisien Gini 2010-2015, Surabaya lebih baik daripada Jakarta, namun di atas Medan. Ini berarti kesenjangan di Surabaya di atas Medan. Pengangguran terbuka di Surabaya (20102015) merupakan terendah dibandingkan Jakarta dan Medan. Meskipun demikian persentase penduduk miskin masih di atas Jakarta, tetapi di bawah Medan.

Persentase penduduk miskin dan pengangguran terbuka di Medan tertinggi dibandingkan Jakarta dan Surabaya. Ini menunjukan bahwa di Medan diperlukan penambahan fasilitas pendidikan dan kesehatan serta kesempatan kerja baru. Data menunjukkan bahwa Medan dengan PDRB terendah (2011-2015) juga memiliki IPM terendah (2013-2015) dan kesenjangan terendah (2014-2016) dibandingkan Jakarta dan Surabaya.

\section{PENUTUP}

Tingkat urbanisasi di Jakarta dan Medan meningkat pesat dalam periode 2010-2016. Urbanisasi mempunyai peranan dalam menyediakan sumber daya manusia bagi pembangunan ekonomi yang diukur dari Produk Domestik Regional Bruto (PDRB). Besarnya PDRB dan urbanisasi memberi kesempatan penduduk untuk menikmati hasil pembangunan. Meskipun Jakarta mengalami urbanisasi terbesar dan memiliki PDRB tertinggi, namun bukan Jakarta yang memiliki Indek Pembangunan Manusia (IPM) tertinggi. Ternyata Surabaya memiliki IPMtertinggi daripada IPM Jakarta dan Medan. Ini menunjukkan bahwa mereka yang tinggal di kota besar seperti Jakarta dan Surabaya mempunyai kesempatan lebih besar untuk meningkatkan taraf hidupnya. 
Di lain pihak, PDRB Medan terendah dibandingkan Jakarta dan Surabaya. Rendahnya PDRB Medan juga diikuti dengan rendahnya IPM. Perkembangan angka IPM yang dicapai Medan dalam pembangunan manusia tidak terlalu signifikan. Persentase penduduk miskin dan pengangguran terbuka di Medan tertinggi dibandingkan Jakarta dan Surabaya. Ini menunjukkan bahwa Medan membutuhkan penambahan fasilitas pendidikan dan kesehatan untuk memperbaiki IPM serta kesempatan kerja baru seperti Usaha Kecil Menengah untuk menurunkan tingkat pengangguran terbuka dan kemiskinan. Data menunjukkan bahwa Medan dengan PDRB terendah (2011-2015) juga memiliki IPM terendah (2013-2015) dan kesenjangan terendah (2014-2016) dibandingkan Jakarta dan Surabaya. Dari uraian di atas dapat disimpulkan Medan menjadi kota yang kurang nyaman untuk ditinggali. Dampak urbanisasi terhadap proses pembangunan sebenarnya jauh lebih luas daripada dampaknya atas semakin parahnya pengangguran terbuka dan setengah pengangguran di perkotaan.

\section{DAFTAR RUJUKAN}

Abbas, Ardi. (2002). Sosiologi Perkotaan, Padang: Universitas Andalas

Badan Pusat Statistik, Data Dan Informasi Kemiskinan Kabupaten/Kota 2010-2016 . Indeks Pembangunan Manusia 2016

- Indikator Kesejahteraan Rakyat Provinsi DKI Jakarta 2017

. Jakarta dalam Angka 2010-2016

Medan dalam Angka 2010-2015

Surabaya dalam Angka 2010-2015

Engineer, Merwan, King, Ian and Roy, Nilanjana (2008). "The human development index as a criterion for optimal planning", Indian Growth and Development Review, 1 (2), 172-192

Hutajulu, Iwan P. (1985). "Urbanisasi dan Implikasi Sosial-Ekonomisnya terhadap Migran", Analisa, XIV (7), 583-597.

Kanbur, Ravi and Zhuang, Juzhong (2013). "Urbanization and Inequality in Asia", Asian Development Review, 30 (1), 131-147

Lewis, Blane D (2014) "Urbanization and Economic Growth in Indonesia: Good News, Bad News and (Possible) Local Government Mitigation”, Regional Studies, 48 (1), 192-207.

Kuncoro, Mudrajad (2017). Ketimpangan Indonesia: Tren, Penyebab dan Terobosan Kebijakan, makalah seminar nasional ISEI di Lampung, 18 Oktober (tidak diterbitkan).

Nguyen, Ha Minh and Nguyen Le Dang (2017). "The relationship between urbanization and economic growth: An empirical study on ASEAN countries", International Journal of Social Economics, 45 (2), 316-339.

Patty, Mudrajad Kuncoro (2016). "The Linkage Between Industrializaion, Urbanization and Tourism: Lesson From ASEAN and Indonesia",International Journal of Business, Economics and Law, 11 (3), Dec 33-43.

Prasodjo, Iwan (2000). "Pengangguran dan Setengah Pengangguran Akibat Krisis Moneter di Perkotaan 1997-1999", Jurnal Ekonomi, V (02), 1-8.

(2013). "Peranan Desentralisasi Fiskal Terhadap Peningkatan Kesejahteraan Masyarakat, Studi Kasus: Provinsi Riau, DKI Jakarta dan Kalimantan Timur 2010-2012,Jurnal Ekonomi, XVIII (01), 122-136. 
Ram, Rati (2009). "Intercountry inequality in human development: a 30-year perspective," Journal of Economics Studies, 36 (5), 481-489

Tanuwidjaja, Enrico (2005). "Economic Growth and Income Inequality: Case Study on Indonesia (Pre Crisis). Jurnal Ekonomi, X (01), 1-34

Winarti, Astri (2014). Analisis Pengaruh Pengeluaran Pemerintah Bidang Pendidikan, Kemiskinan, dan PDB Terhadap Indeks Pembangunan Manusia di Indonesia periode 1992-2012, Skripsi di Fakultas Ekonomika dan Bisnis, Universitas Diponegoro, Semarang. (tidak diterbitkan)

Butar Butar, Novyta Ma'antri (2014). "Pengaruh Urbanisasi terhadap Tercapainya Pembangunan Ekonomi”, http://gogreeneconomy.wordpress.com/2014/09/30/pengaruh-urbanisasiterhadap-tercapainya-pembangunan-elonomi

Indonesia's Human Development Index Rises but Inequality Remains(http://www.id.undp.org/content/indonesia/en/home/presscenter/press releases/2017/03/22/indonesia-s-human-development-index-rises-butinequality)

http://Surabayakota.bps.go.id 